\title{
Challenges and Solutions to Islamic Banking System in a Pluralistic-Secular Country like Nigeria
}

\author{
Audu Bello \\ Department of Economics, Usmanu Danfodiyo University, \\ P.M.B. 2346, Nigeria \\ Email: ecobello42@yahoo.com \\ Mika'ilu Abubakar \\ Department of Economics, Usmanu Danfodiyo University \\ P.M.B. 2346 Sokoto, Nigeria \\ Email:mikabakr@yahoo.co.uk
}

\section{Doi:10.5901/mjss.2014.v5n6p25}

\begin{abstract}
The objective of this paper is to assess the challenges that the introduction of Islamic banking in Nigeria may face. It is also aimed at providing solutions to these challenges. In doing this, the study resolves that the challenges that may confront Islamic banking in Nigeria are institutional challenges such as inappropriate institutional framework, inadequate legal framework, lack of equity institutions, poor supervisory framework, disparity in accounting standard, lack of secondary financial markets and lack of short-term financial instruments and institutions. The operational challenges in the form of religious and cultural differences, lack of innovations in financial products, lack of profit sharing finance, shari'ah related issues, inadequate manpower with the requisite knowledge, lack of awareness and competition. In the presence of these hurdles, the study concludes that the proposed Islamic banking in Nigeria should take the bull by the horns in order to overcome these challenges.
\end{abstract}

Keywords: Islamic banking, pluralistic, secular, shari'ah

\section{Introduction}

The issue of establishing Islamic banking (bank based on Shari'ah) in Nigeria is not new. Various efforts have been made to see it come through by some concerned Nigerian Muslims and non-Muslims but faced all sorts of challenges and oppositions due to differences in culture and religion, and as a result of lack of awareness about the system. With all these challenges and oppositions, a careful consideration of the Nigeria banking law led to the promulgation of Decree No. 46 of 1992 which provides avenue for each community to establish community banking which can operate based on its own customs and tradition. This according to Malami (2009) prompted the establishment of Haraka Islamic Community Bank in Sokoto town. The bank operated strictly on the basis of Islam but did not record any successful achievements due to lack of adequate personnel, low capital base, nonchalant attitude of staff, and inadequate awareness of the system etc.

However, modern Islamic banking in Nigeria evolved as far back as 1991 with the enactment of the Banks and other Financial Institutions Decrees. Sections 23 and 61 of this Decree recognized profit and loss sharing banks. However, there were no significant achievements due to lack of compliance with Central Bank of Nigeria's requirement by potential investors. In 1996, Central Bank of Nigeria approved the defunct Habib Bank Plc. to open an Islamic banking window which was not successful due to lack of full-fledged Islamic banking in the country. Furthermore, in 2004 Ja'iz International demanded approval for the establishment of full-fledged Islamic bank which was given approval in principle upon meeting the mandatory capital requirement. In line with the struggle to have Islamic banking, in 2005 Financial System Strategy launched a blueprint to engineer Nigeria's transformation into the 20 largest economies in the world by the year 2020. Among its initiatives regarding money market is to create Islamic banking in Nigeria. In 2008 the Islamic Finance Working Group was founded and was highly supported by Enhancing Financial Innovation and Access, Nigeria Deposit Insurance Corporation, National Insurance Commission, Pension Commission, Debt Management Office, Central Bank of Nigeria among others. In addition, the CBN joined the Islamic Financial Service Board (IFSB) as a full council 
member in 2009, and issue the draft framework for the regulation and supervision of Islamic banking in Nigeria for stakeholders' comments and suggestions in that same year. In line with the opinions of the stakeholders, the Central Bank of Nigeria released the new banking model which designated Islamic banks among the specialized banks in 2010. The NDIC also released a draft framework for Islamic deposit insurance scheme for comments and suggestion from stakeholders. Despite all the hurdles of establishing Islamic banking in Nigeria, the CBN joined 11 other central banks and 2 multilateral organizations to form the International Islamic Liquidity Management Corporation (IILM) with headquarters in Malaysia. Finally, in 2011 the Central Bank of Nigeria released the framework for the regulation and supervision of Islamic banking in Nigeria, and gave approval in principle to some potential investors upon meeting the mandatory requirement of the CBN (Sanusi, 2011).

It is the conclusion of many studies (see for instance Sanusi, 2011; Iqbal et al. 1998; Dusuki and Aboizaid, 2007; Malik et al. 2011; Ariss and Sarieddine, 2007; Njamike, 2010; and Iqbal, 2001) that the establishment of Islamic banking in any country be it Muslim or non-Muslim faces a number of challenges and Nigeria is not an exception. These challenges could be institutional or operational, but they are not without remedies. According to Nijzink (2009) many studies were conducted on Islamic financial institutions especially banks after the recent global financial crisis to assess why most Islamic banks were not affected by the crisis. In the wake of this development, Jaiz bank (the first major Islamic bank with 9 branches across the country as at July 2013) became operational. It should however, be understood that specialized banks such as Islamic banks are not without challenges. Accordingly, this study seeks to assess the challenges that the introduction of Islamic banking in Nigeria may face and offer solutions that can overcome these challenges and problems.

The remaining part of this paper is organized as follows. Section two presents the conceptual framework of Islamic banking which is followed by literature review related to challenges of Islamic banking. In section four, justification for Islamic banking in Nigeria is presented. The fifth section is devoted to the discussion of the challenges and steps forward for Islamic banking in Nigeria. The final section concludes the paper and offers recommendations.

\section{Conceptual Framework}

This section provide an explanation of Islamic banking by differentiating it from Islamic banking window, it explains the concept of Riba (interest), basic principles (features) of Islamic banking, modes of operation, and justifications of Islamic banking system in Nigeria.

\subsection{Definition of Islamic Banking}

The definitions of Islamic banking revolved around one thing - Islamic law (Shari'ah). This can be understood in the following definitions from different authors. For instance, Sanusi (2011) views Islamic banking as an alternative form of financial intermediation that is based on profit motive. That is, Islamic banking is market driven but with a moral dimension based on the Islamic value system. Akram et al. (2011) see Islamic banking as that banking system which is run in accordance with the Islamic laws and the Shari'ah board; that guides the institutions. Furthermore, Lawal (2010) defined Islamic banking as a system of banking that is consistent with the principles of Islamic law (Shari'ah) and its application through the development of Islamic economies. In addition, Marimuthu et al. (2010) define it as the conduct of banking based on Shari'ah principles. In the same line, Ghayad (2008) sees Islamic banking as a banking system that operates in accordance with the rules of Shari'ah i.e. Figh al-Muamalat (Islamic rules on transactions). In conclusion, Islamic banking is a kind of banking system that operates strictly on the basis of Shari'ah (Islamic law).

A concept mistaken for Islamic banking is Islamic banking window operated by some commercial banks. Sanusi (2011) defines Islamic banking window as a business model in which conventional banks offer Islamic banking products and services from their existing network. In short, Islamic banking window refers to a situation whereby a conventional banking system provides some of the Islamic banking products or services. In other words, it can be seen as a banking system that meets up only the profit, loss, and risk sharing principle of Islamic banking for some of its products. A typical example in the Nigeria context was the case of the defunct Habib Bank Plc which was permitted to provide some Islamic banking products by the Central Bank of Nigeria.

\subsection{The Concept of Riba (interest)}

Riba which is the same thing as interest or usury has been defined differently by different scholars. Some of these scholars see it to mean the same thing, while some try to differentiate it from interest charged in the conventional banking 
system without winning the debate. Then what is Riba? Riba literally means the 'increase' or 'excess' above the principle on a loan (Abraham, 2008). Abraham goes on to say that riba means usury since it is an inherently illegitimate practice which has been condemned in the Qur'an. More so, Seed (1996) in Lawal (2010) defines riba as an amount over the principal of a loan paid to the capital owner because of his extension of maturity for his debtor, and deferment of repayment of debt. Furthermore, riba literally means excess or increase, and technically as an increase over principal in a loan transaction or in exchange for a commodity accrued to the owner (lender) without giving an equivalent recompense in return to the other party; even increase which is without an equal counter-value. Riba is however divided into two: Riba al-Fadl and Riba al-Nasiah. Riba al-Fadl is the type of riba that is associated with quality in direct exchange of commodities. It means the quality premium in exchange of low quality with better quality commodities. The concept of Riba al-Fadl refers to sale transactions. While Riba al-Nasiah means an increment on principal of a loan or debt payable. It also refers to the practice of lending money for any length of time on the understanding that the borrower would return to the lender at the end of the period the amount originally lent together with an increase on it, in consideration of the lender having granted him time to pay irrespective of loss or profit. Interest, in all modern banking transactions, falls under Riba al-Nasiah. In the current banking system, as money is exchange for money with excess and delay, it falls under the definition of Riba which has been prohibited in Islam no matter the name you call it. More precisely, riba means any positive, fixed, predetermined rate tied to the maturity and the amount of the principal - that is, guaranteed regardless of the performance of the investment (Greuning and lqbal, 2008). Conclusively, riba means an increase or excess of the principle of a loan.

However, Islam prohibits Muslims from taking or giving interest (riba) regardless of the purpose for which such loans are given as well as its rate. The prohibition of interest (riba) is mentioned in four different revelations in the holy Qur'an. The first revelation emphasizes that interest (riba) deprives wealth of God's blessings. The second revelation condemns interest (riba), placing interest (riba) in juxtaposition with wrongful appropriation of property belonging to others. The third revelation enjoins Muslims to stay clear of interest (riba) for the sake of their own welfare. And finally, the fourth revelation establishes a clear distinction between interest and trade, urging Muslims to take only the principal sum and to forgo even this sum if the borrower is unable to repay. It is further declared in the Qur'an that those who disregard the prohibition of interest (riba) are at war with God and His Prophet. More so, the Prophet also condemned not only those who take interest (riba) but also those who give interest and those who record or witness the transaction, saying that they are all alike in guilt. Thus, by Islamic bank operating on free interest (riba) basis, it satisfies the interest (riba) - prohibition rule of Islam which cannot be achieved in the conventional banking system (Ariff, 1988)

\subsection{Basic Principles (Features) of Islamic Bank}

Islamic banking is a unique type of banking system that devoids all forms of transactions that are prohibited in Islam. So for any bank to be classified as Islamic bank, the following basic principles must be adopted for its operations (Greuning and Iqbal, 2008; Abraham, 2008; Islamic Financial Stability Forum, 2010; and Sanusi, 2011):

a) Prohibition of interest (Riba). Interest means a fixed predetermined amount in addition to the principal. It is prohibited in Islam. So for any bank to be called Islamic bank, it must not engage in any interest related transactions, but rather, profit and loss sharing transactions.

b) Prohibition of speculation (gharar). The term gharar literally means hazard. More so, it means transactions that have too much risk and are therefore linked to gambling. Since Islam prohibits speculation, a potential Islamic bank will avoid all transactions with excessive risk.

c) Profit, loss, and risk sharing. Since interest is prohibited in Islam, the providers of funds and the entrepreneur in an Islamic banking settings share the business risk and profits based on mutual agreement. This act will equitably distribute income, enhance social justice, and alleviate poverty etc.

d) Shari'ah approved activities. Islamic banking is a banking system that is based on Shari'ah. So any transactions that are prohibited by Shari'ah in the likes of alcohol, gambling etc. are avoided in Islamic banking. Islamic banks can only partake in transactions or activities that are approved by the Shari'ah advisors.

e) Social Justice. Islam prohibits Muslims from any transactions leading to injustice and exploitation of any kind. So Islamic banks can not engage in any transactions that will lead to exploitation of any party.

f) Compulsory payment of zakat. It is mandatory for an Islamic bank to pay zakat. Zakat is one of the five pillars of Islam. 
g) Overseen by Shari'ah advisors. Every Islamic bank must be regulated by experts in Islamic law who will have to audit the operations of Islamic banks and its products to make sure that they comply with Shari'ah guidelines.

\subsection{Modes of Operation in Islamic Banking}

The modes of operation of Islamic banking are numerous and there is room for further innovation in the modes of operation provided they are in line with shari'ah's principles. Below however, we restrict ourselves to the popular ones:

a) Qard Hasan loans: It is a benevolent loan given to deserving customers by Islamic banks to alleviate poverty. The beneficiary is required by Shari'ah to pay back only the principal to the Islamic bank. However, the client may pay an addition to show appreciation to the Islamic bank but this intention should not be disclosed to the bank by the customer at the beginning of the transaction.

b) Mudarabah (Silent Partnership): A mudarabah contract is a financial transaction in which there are two partners in the contract. One of the partners will provide the needed capital (Rabb-ul-Maal) and the other partner will go into the business as entrepreneur (Mudarib). That is, the Islamic bank will act as the capital provider (Rabb-ul-Maal). In this type of financial contract, profits are shared between Islamic bank and the entrepreneur (client) based on predetermined ratio. However, in the event of loss the Islamic bank (or depositors) bears the loss while the entrepreneur loses his or her effort provided it was not as a result of his or her negligence. Mudarabah contract is of two parts in Islamic banking system. One part of the contract is between the Islamic bank and the depositors, and the second part is between the Islamic bank and the entrepreneur.

c) Murabahah (Cost-Plus Sale Contract): This type of contract is mostly use in the procurement of equipment. It is a sale contract between Islamic bank and its client at a fixed profit called mark-up. In this contract, the client will provide all the specifications of the commodity and the Islamic bank will take the risk of purchasing it for the client at a cost plus mark-up which the client can either pay in installment or sum at a spot or at a stated period.

d) ljarah (Lease): Ijarah is synonymous to leasing contract in conventional banking. It is a contract whereby an Islamic bank purchases an asset and leases it out to its client on the agreement that the client will be paying a fixed amount at regular interval usually monthly for a specified period of time to the Islamic bank. It may also include the option of the client purchasing the asset at the end of the contract from the bank.

e) Musharaqa (Equity Partnership): Musharaqa is a contract in which two or more persons contribute capital for the establishment of a particular business venture in such a way that each partner has right to either involve in the administration of the business or not. However, partners may decide to be active or sleeping partner at their own will. In this kind of transaction in Islamic banking, profits are shared based on agreed ratio which need not be equal to their individual capital contribution, but loss is shared strictly based on individual capital contribution. So, Islamic bank will act as a partner in this case in order to contribute in the capital formation as well as in sharing profits and loss.

f) Salam (Forward Trade Contract): This is a sale contract whereby Islamic bank agrees to supply some specific commodities to the buyer (its client) at a future date that is specified in exchange of an advanced full spot payment to the bank. That is, the client pays the full amount and delivery of the commodity to the client is done in specific future date by the Islamic bank.

\section{Literature Review}

Studies on challenges of Islamic banking have been conducted all over the world in other to enhance the establishment of Islamic banking as well as its operation. However, some of these studies are based on a single country experience (Jabr, 2003; Saleh et al, 2007; Amin, 2008; Sanusi, 2011; Akram et al, 2011; and Njanike, 2010) while others are based on the general system (Iqbal et al, 1998; Ariss et al, 2007; Shaukat et al, 2011; Iqbal, 2001; Dusuki and Aboizaid, 2007; and Ahmad et al, 2011). Single country studies are studies based on a particular country experience, while general system studies are studies based on the general system of Islamic finance.

\subsection{Review of Country-Specific Studies}

In this section we review country-specific studies beginning with the study by Akram et al. (2011) which employed 
descriptive analysis to examine the growth and development as well as prospects of Pakistani Islamic banking system. The study finds that there is tremendous increase in the sources and uses of Islamic banking funds, indicating growth and development of Islamic banking in Pakistan. In addition, they state that the prospects of Islamic banking in Pakistan depends on the fact that it is a Muslim country. The authors are of the opinion that Islamic banking branch network will improve in the future, due to the increasing interest of conventional banks in Islamic banking activities and functions in Pakistan, and the improvement in Islamic banking performance. However, Akram et al. argue that the major challenges of Islamic banking in Pakistan are competition and cultural differences.

Amin (2008) studied e-business from Islamic perspective as well as its prospects and challenges in Malaysian finance. Amin argues that the prospects of e-business of Malaysia depend on government support, Islamic financial system liberalization, economies of scale, the improvement in manpower, and growing users of internet facilities. However, Islamic e-business challenges are lack of consumer acceptance, pricing in Islamic e-business, the need for complex infrastructure, and legal risks issues.

Jabr (2003) concludes that the challenges and prospects of Islamic banks operating in the Palestinian territories are as follows: Lack of adequate banking law for Islamic banking; existence of unproductive money; lack of awareness; lack of operational difference between Islamic and conventional banks; Islamic banking lacks the ability to channel deposits into long-term investment; lack of experience in Islamic Shari'ah; excessive short-term financial instrument; inability to make use of Mudaraba and Musharaka financial institutions; inferior technical resources and technology; Islamic banks are compel to recruit staff trained in traditional banking; inability to differentiate ownership from management; and lack of financial innovations.

Njanike (2010) adopts descriptive analysis to explore the problems and challenges that the introduction of Islamic banking in Zimbabwe may likely face. The study finds that the major problems and challenges in introducing Islamic banking in Zimbabwe are political intervention in the selection of borrowers, financial instability, inability of the government to restore law and order in the country, resistance from the banking community, inadequate infrastructure for information dissemination, inconsistency in policy making and implementation of the fiscal and monetary authorities, Central bank control and supervision of Islamic banking with unqualified persons in Islamic finance, absence of Islamic interbank, misperception, current political and economic situation, and default culture.

Saleh et al. (2005) adopt ratio analysis to examine the Lebanese experience with Islamic banking since the foundation of the first Islamic bank. They find that lack of public awareness and acceptance, lack of research and development institutions, inadequate manpower, and high competition from conventional banks offering Islamic windows are the major challenges of Islamic banking in Lebanon. They were however, optimistic that Islamic banking in Lebanon will prosper because of its ability to attract more investment and capital into the country, the vital role it plays in financing and developing telecommunications, agriculture, industry sectors in the Lebanese economy, its long term strategy to increase its customer base, and its current support from the general public as well as private business.

Finally, Sanusi (2011) explores the issues and challenges of Islamic banking in Nigeria. The study finds that the challenges of Islamic banking in Nigeria are inadequate manpower, lack of Shari'ah - compliant liquidity management instruments, lack of Islamic insurance (Takaful), lack of knowledge of accounting and auditing standard require by Islamic financial institutions, inadequate legal framework, lack of Shari'ah scholars knowledgeable in conventional economics, law, accounting, banking and finance, problem of multiple taxation, lack of tax relief on Islamic banking profits, and misperception of Islamic banking in Nigeria.

\subsection{Review of General System Studies}

A review of general system studies is rendered in this section. We start with the study by Ahmad et al. (2010) that analyzed the working of Takaful and its popularity in the global insurance sector. They are of the view that inadequate qualified staff in both conventional insurance and Shari'ah finance, lack of awareness, application of International Financial Reporting Standard (IFRS) instead of AAOIFI standard in countries where Takaful is new, inadequate short term financial instruments, lack of financial innovations, inadequate interpretation of what constitute Takaful, lack of organization to regulate Takaful, inadequate human resources with the require knowledge, and the disparity in the approach of accounting practices and Shari'ah law are the challenges of Takaful.

Ariss et al. (2007) investigate the guidelines for risk management and capital adequacy in Islamic banking. The study concludes that the proposed guidelines of Pillar 1 of the Basel II Accord disregard the sources of funds of a conventional bank and assess only the risk of its activities arising from the uses of such funds. This means that the proposed guidelines are bias to Islamic banking system. The study further states that the other challenges of Islamic banking are liquidity risk, lack of wide range of derivative instruments, and complications in measuring Shari'ah compliant 
risk.

Dusuki and Aboizaid (2007) assessed the challenges in realizing the maqaeid al-Shari'ah in contemporary economics transactions. They conclude that the major challenges are inadequate understanding of maqaeid al-Shari'ah and various tools in Islamic law, inability to understand the very aims of Shari'ah and its application to modern transactions, and finally circumventing the prohibition of riba.

Iqbal (2001) opines that the challenges facing Islamic financial industry are limited set of short terms financial instrument and inadequate medium - to long - term financial instruments, limited coverage of Islamic finance, concentration of Islamic banking, poor risk management and governance framework, and difference between Islamic finance in theory and in practice. The author recommends adequate risk management and diversification of the institution, provision of non - banking financial services, and development of capital markets that are Islamically inclined to improve its activities and functions, and be able to compete favourably.

Iqbal et al. (1998) opine that the challenges hindering Islamic banking are institutional as well as operational challenges. The institutional challenges are poor institutional framework, inadequate legal framework and supervisory policies, poor supervisory framework, disparity in accounting standards, lack of equity institutions, absent of organized secondary financial market, and lack of short term market placement of funds. While the operational challenges are improper financial engineering, lack of teaching, training, research and development in this institution, lack of profit sharing finance, inability to adequately mobilize deposits, competition, and finally globalization.

Finally, Shaukat et al. (2011) are of the opinion that the lack of ultimate authority that governs Islamic financial industry, inadequate qualified human resource in both conventional banking and Islamic laws, illiquidity of Islamic long term assets with short - term liabilities, lack of Shari'ah auditing standard personnel, and shortage of short - term investment products are the challenges of Islamic banking system. They further state that the other challenges facing Islamic banking system are lack of innovation, lack of adherence to local regulatory reporting and operational requirements, lack of transparency and accountability, operating manually, and lack of high quality services.

In short, from both single country as well as general studies on Islamic finance, one can deduce that the importance of adequate human resources qualified in Islamic and conventional settings, financial innovations, awareness, adequate provision of both short- and long-term financial instruments, proper Shari'ah regulating body, adequate legal framework, proper institutional framework etc. cannot be over looked in order to improve this institution.

\section{Justification for Islamic Banking System in Nigeria}

Islamic banking in Nigeria is very feasible due to the fact that it has been generally accepted the world all over that there is need for a re - thinking in the operations of the current financial system that led to the current global financial crisis. The following reasons are given below to buttress the justification of Islamic banking in Africa's most populous country.

The recent Global Financial Crisis which affected almost all countries of the world. It is very surprising to note that despite the devastating effect of the global financial crisis on the giant financial institutions all over, Islamic banking system was marginally or not affected. Furthermore, while the global financial crisis wreak havoc on financial institutions around the globe, the Islamic banking system increased in their reserves as well as attracting new clients. With this, a good number of Islamic banking institutions were been opened in most Western countries in other to benefit from it, so why not Nigeria?

The next reason has to do with the Constitutional provision of Nigeria. The 1999 Constitution of Nigeria provides the right to freedom of thought, conscience, and religion which cuts across all human endeavors. Since Muslims are prohibited from engaging in interest based transactions, this necessitates the establishment of Islamic banking system to enable Muslims exercise their constitutional right which is not a privilege. On this ground, Islamic banking is justified in Nigeria with full constitutional backing (Abikan, 2009).

More so, Islamic banking system provides their clients choice of investment. Malami (2009) states that Islamic banking provides their clients the choice of investment with respect to time deposit account. This provision cannot be provided by conventional banking system. In Islamic banking system, time deposit account is divided into two - general and specific investment account. Under the general investment account, the bank will invest investors' fund in any sector they see fit provided it is in line with the Shari'ah. While under the specific investment account, the costumers will specify the sector for which their fund should be invested by the bank. And in this case, the bank will not deviate from the customer's choice of investment. So in essence, since the Islamic banking provides their customers the choice of investment which the conventional banking cannot provide, Islamic banking is justified in Nigeria.

In addition, Central Bank of Nigeria has launched new regulating framework for Islamic banking because it cannot isolate itself from the global transformation in the financial system brought about by Islamic finance. More to that, there is 
a large market for Islamic banking institutions in terms of large number of Muslims in northern and south-western parts of the country who are ready to benefit from Islamic banking services. This reason also justifies Islamic banking in Nigeria.

Finally, if Islamic banking can be allowed in predominantly non-Muslim countries as is the case in some western countries, then Nigeria that has a Muslim majority deserve Islamic banking services. The architecture of Islamic financial institutions is advantageous to every economy because it enhances equitable distribute of income, operate interest free transactions, invest in only lawful investments and in real sector of the economy. In conclusion, Islamic banking system is highly justified in Nigeria if the country wants to bridge the gap between the poor and the rich.

From the above reasons, one can logically conclude that Islamic finance is highly justify in Nigeria no matter the challenges and oppositions to it.

\section{Challenges and the Steps Forward}

The challenges confronting every Islamic banking system the world over could be categorized into institutional challenges and operational challenges. Institutional challenges are those challenges that are unique to Islamic banking institutions while the operational challenges are those challenges confronting the operations of Islamic banking. In the case of Nigeria, the challenges that it may likely face are also categorized into institutional and operational challenges given below with their possible solutions.

\subsection{Institutional Challenges}

The institutional challenges that may likely hinder the successful establishment and management of Islamic banking in Nigeria are as follows:

a) Inappropriate Institutional Framework

The nascent Islamic banking in Nigeria will be hindered by the current institutional framework that supports conventional banking. This is because the current institutional framework is structure in the line of conventional financial system which is against Islamic banking. The step forward is for Central Bank of Nigeria to either modify the exiting framework or introduce special framework for Islamic banking in order to provide adequate support for the establishment and operation of Islamic banking in Nigeria. The Central Bank of Nigeria has really tried in this aspect but still needs to do more.

b) Inadequate Legal Framework

The exiting legal framework in Nigeria is also a major setback to Islamic banking due to the fact that it is design to suit the conventional settings. Islamic banking cannot adequately operate if there is no special legal framework for its institutions. This can be understood from the fact that as Islamic banking operates on Shari'ah basis, the enforcement of such operations in the court of law is another problem without implementing Islamic laws in Nigerian legal system. The only way out is for the introduction of special laws for the operation of Islamic banking in Nigeria.

c) Lack of Equity Institution

It is generally accepted that the need for long term finance cannot be overestimated in any financial institution. This is another challenge that Islamic banking in Nigeria may need to address in order to enhance its operations. This is because the existing institutions that provide such facilities operate on interest basis which is against Islamic banking principle. For Nigerian Islamic banking to operate effectively, there should be institutions that will provide long term finance such as bonds and equity on Shari'ah principle.

d) Poor Supervisory Framework

Islamic banking in Nigeria may face the challenge of ineffective supervisory framework from the Central Bank of Nigeria as well as the Shari'ah advisory board. This is as a result of the fact that the two bodies may end up contradicting issues instead of complementing each other, and the shortage of Shari;ah scholars as well as Central Bank of Nigeria's supervisors with the require knowledge. In order to overcome this, the role of the CBN and that of the Shari'ah board should be structured in such a way that it adequately regulate and supervise Islamic banking activities as well as protects public interest in Islamic banking in Nigeria with qualified persons in such areas.

e) Disparity in Accounting Standard

Islamic banking in Nigeria may be challenged by the disparity in their accounting standard as experienced all over the world. However, the existing commercial banking system has similar accounting standard which enable easy supervision and regulation of their operations by the Central Bank of Nigeria. This issue has been 
reduced by the standard set aside by the Accounting and Auditing Organization for Islamic Financial Institutions (AAOIFI). In that case, the Central Bank of Nigeria should prescribe and implement this standard to all potential Islamic banks in Nigeria in order to ease its supervision and regulation.

f) Lack of Short-Term Financial Instruments and Institutions

The lack of inter-bank transactions among Islamic banking due to their fewness leads to inadequate short term financial institutions and instruments. Islamic banking is however, in high need of short term institutions and instrument for effectively and efficient operations. For Nigerian Islamic banking to effective flourish, there should be more participants in Islamic banking in Nigeria in order to enhance inter-bank transactions based on Shari'ah principles.

g) Absence of Secondary Financial Market

Lack of secondary financial markets is another challenge that Islamic banking in Nigeria may likely face. This is because the existing secondary financial markets operate on interest basis which is against Islamic ethics. For Islamic banking in Nigeria to operate adequately, there should be secondary financial markets that operate on Shari'ah basis. This can be addressed by Islamic banking establishing secondary financial markets in Nigeria. This will make Islamic banking assets more liquid and attractive. This is necessary for Islamic banking in order to be able to adequately mobilize funds in Nigeria.

\subsection{Operational Challenges}

The operation of Islamic banking in Nigeria may likely be confronted by the following challenges:

a) Religious and Cultural Differences

One of the major challenges of Islamic banking in Nigeria has to do with the country's multiple cultural and religious belief. This issue is a serious one that needs to be effectively and efficiently resolved if Islamic banking in Nigeria must prosper. This is because of the fact that others with different cultural and religious belief will have a misperception of the institutions that may lead to not accepting the institution by the general public. This particular challenge of Islamic banking can be addressed only through the help of Central Bank of Nigeria, religious bodies, and Islamic banking institutions by creating adequate awareness about the needs, objectives and the advantages of the institutions. This is necessary if Islamic banking in Nigeria must survive and achieve its objectives as prescribe by Shari'ah.

b) Inadequate of Financial Innovations

As financial markets are changing with time, there is the need to design financial products that will meet the needs and tastes of the users with regards to risk involve in the maturity of the instruments and return from such instruments in any financial institutions which Islamic banking is not an exception. However, there is inadequate financial innovations or delay in implementing innovated products in Islamic banking due to Shari;ah guidelines requirement. This makes Islamic banking to be relatively rigid to innovations. In order to exploit the fast changing market environment and face increasing competition squarely, financial innovations in Islamic Finance are vital and should be encouraged in advance.

c) Lack of Profit Sharing Finance

Islamic banking in Nigeria may likely be hindered by lack of profit sharing financial instruments. Islamic banking transactions are divided into fixed charge and profit sharing. The proponents of Islamic banking built up Islamic banking in the hope that it will operate on profit sharing basis. However in practice, profit sharing finance has remained relatively small in the operation of Islamic banking. This is a serious challenge to Islamic banking in the sense that one of the major reason for Islamic banking is to operate on profit sharing basis. The Central Bank of Nigeria should encourage Islamic banking in Nigeria to provide more profit sharing finance.

d) Shari'ah Related Issues

Due to the fact that Islamic banking has religious dimension, financial innovations in this institution needs to meet Shari'ah requirements. That is, any new financial products in Islamic banking cannot be adopted until it is approve by the Shari'ah advisory board and also followed by post Shari'ah auditing. However, this act delays Islamic banking ability to take advantage of changing financial environment due to the fact that time has to be wasted before it is finally approve by the Shari'ah board. This act is very vital for Islamic banking in order to protect their clients' confidence in the institution. So Islamic banking should have varieties of financial instruments as well as products that have been approved in advance by the Shari'ah board in order to overcome any delay that changes brought about in the financial environment may cause in its adopting new products and instruments in the future. 
e) Inadequate Human Resources

The survival of Islamic banking in Nigeria highly depends on adequately qualified human resources in teaching, training and research in Islamic Finance with knowledge in both Islamic and conventional finance as well as economics. In the case of teaching and research, only a handful of universities at present can be said to have been teaching as well as conducting research in both Islamic Finance and the conventional settings. The output of such research findings and human capital development in the both settings need to be improved if the institution must survive in Nigeria. This is because using indigenous labour will be cost effective compare to importing labour service from outside the country. However, in the case of training in Islamic banking, little or no effort has been made in this aspect. And this is very detrimental to the survival of Islamic banking in Nigeria. The step forward for Islamic banking in Nigeria with respect to human resources problems is to adequately fund institutions teaching and conducting research in both settings and establish more institutions in Nigeria. In addition, the Central Bank of Nigeria should organize training on Islamic Finance for students in tertiary institutions, bankers, researchers etc. The $\mathrm{CBN}$ can as well send them outside for further training that will have multiple effects in the institution.

f) Inadequate awareness

Islamic banking in Nigeria will be challenged by lack of information about the objectives, principles, and advantages of Islamic banking in the country. There is a dearth of information about Islamic banking in Nigeria even among Muslins. Majority Muslims only know that Islamic banking is based on non-interest basis, while the majority of the followers of other faiths have little or no knowledge about it at all. This is a serious setback to Islamic banking in Nigeria thereby leading to unnecessary oppositions and lack of public acceptance. The Central Bank of Nigeria is really doing great in this aspect but still needs to carry it to the grass root level, and any potential Islamic banking in Nigeria should also assist in creating awareness to enhance public acceptance of the institution.

g) Competition

Islamic banking is an institution that took the world by surprise in development and growth. Islamic banking is now facing serious competition in the financial system as some conventional banks are now converting to full fledge Islamic banks or providing Islamic banking windows. These banks are more developed in all aspects of financial transactions that will increase competition facing Islamic banking. In this case, Islamic banking can survive in Nigeria by increasing its efficiency and performance.

\section{Conclusion}

In order to assess the challenges that the introduction of Islamic banking in Nigeria may likely face, this study is organized into five sections. Section one introduced the study, section two covers conceptual framework on Islamic banking, review of relevant literature is in section three, section four presents challenges and steps forward for Islamic banking in Nigeria, and this final section concludes and makes recommendations of the study.

The study opines that Islamic banking is possible in Nigeria due to the fact that there is a large market for it, it has constitutional backing, its provision of choice of investment to its clients, the new Central Bank of Nigeria's regulatory framework for Islamic finance, its advantages over conventional banking - zero interest rate, equitable distribution of wealth, lawful transactions, promotion of morality in transactions etc. However, Islamic banking in Nigeria will be hindered by both institutional as well as operational challenges. Despite these challenges, Islamic banking will make headway if and only if it can address these challenges objectively.

The recommendations of this study are as follows: first, the three arms of government should address the issue of establishing and operation of Islamic banking in Nigeria objectively. Second, the Central Bank of Nigeria should use all media possible to enlighten the masses on the need for Islamic banking and its objectives in Nigeria. Also, there should be inclusion of laws that will provide Islamic finance avenue to operate in the Stock Exchange and be protected by the laws of Nigeria. Next, religious bodies (Muslim and Christianity) need to be involved in the public campaign for the establishment of Islamic banking in Nigeria. More so, the judiciary should adequately address this issue without fear or favour since it is constitutionally accepted. Finally, Nigerians should not be bias about this institution on the basis of their cultural and religious differences. 


\section{References}

Abikan, A. I. (2009). "Constitutionality of Islamic Banking in Nigeria". In: Justice Tdris Legbo Kutigi (eds) Contemporary Issues in Islamic Jurisprudence. Benin: Rawel Fortune Resources.

Abraham, I. (2008). "Riba and Recognition: Religion Finance and Multiculturalism" Essays from the AASR Conference.

Ahmad, A., Humayoun, A. A. \& Hassan, U. (2010). "An Analysis of Function Performed by Islamic Banking: A Case of Pakistan" European Journal of Social Sciences, 17(1).

Ahmad, M. I, Masood, T. \& Khan, M. S. (2010). "Problems and Prospects of Islamic Banking : a case Study of Takaful". MPRA Paper No. 22232, Posted 20 April, $2010 / 16: 55$

Akram, M., Rafique, M. \& Alam, H. M. (2011). "Prospects of Islamic Banking: Reflection from Pakistan". Australian Journal of Business and Management Research, 1(2).

Amin, H. (2008). "E - Business from Islamic Perspectives: Prospects and Challenges". Journal of Internet Banking and Commerce, $13(3)$.

Ariff, M. (1988). "Research Report on Islamic Banking - Part 1". Asian - Pacific Economic Literature, 2(2).

Ariss, R. T. \& Sarieddine, Y. (2007). "Challenges in implementing capital adequacy guidelines to Islamic banks". Journal of Banking Regulation, 9(1).

Dusuki, A. W. \& Aboizaid, A. (2007). "A Critical Appraisal on the Challenges of Realising MAQAeID AL - SHARI'AH in Islamic Banking and Finance". IIUM Journal of Economics and Management, 15(2)

Ghayad, R. (2008). "Corporate governance and the global performance of Islamic bank" Journal of Humanomics, 24(3).

Greuning, H. V. \& Iqbal, Z (2008). "Risk Analysis for Islamic Banks". The International Bank for Reconstruction and Development/World Bank.

Iqbal M., Ahmad, A. \& Khan, T. (1998). "Challenges Facing Islamic Banking". Islamic Development Bank, and Islamic Research and Training Institute Occasional Paper No. 1.

Iqbal, Z (2001). "Challenges Facing Islamic Financial Industry". Journal of Islamic Economics, Banking and Finance.

Islamic Financial Stability Forum, (2010). "Islamic Finance and Global Financial Stability" Task Force Report of Islamic Development Bank (IDB) Group, Jeddah, Saudi Arabia.

Jabr, H. (2003). "Islamic Banking in Palestine Challenges and Prospects". An - Najah Univ. J. Res. (H.Sc), 17(1).

Malami, H. U. (2009). "Towards Developing Islamic Techniques of Economic Development" Sokoto, Nigeria: Department of Economics, Faculty of Social Sciences, Usmanu Danfodio University.

Malik, M. S., Malik, A. \& Mustafa, W (2011). "Controversies that make Islamic banking controversial: An analysis of issues and challenges". American Journal of Social and Management Sciences, 2(1).

Marimuthu, M., Jing, C. W., Mum, L. P. \& Ping, T. Y (2010). "Islamic Banking: Selection Criteria and Implication". Global Journal of Human Social Science, 10(4).

Njamike, K. (2010). "Introduction of Islamic Banking in Zimbabwe: Problems and Challenges". Journal of Sustainable Development in Africa, 12(8).

Saleh, A. S \& Zeitum, R (2005). "The Development of Islamic Banking in Lebanon: Prospects and Future Challenges". Review of Islamic Economics, 9(2).

Sanusi, L. S. (2011)."Islamic Finance in Nigeria: Issues and Challenges" Lecture Delivered at Markfield Isntitute of Higher Education (MIHE), Leicester, UK, 17 June, 2011.

Shahid, S. (2007). "Role of Islamic banks in economic development" Online at http:// mpra. Ub. Uni - muenchen.de /7332/.MPRA Paper No.7332, Posted 25 Feb., 2008 /16:54. 